\title{
A RETROSPECTIVE 05 YEARS ANALYSIS OF OPERATED SURGICAL PATIENTS IN BANGLADESH LEVEL II HOSPITAL, UNMIL.
}

\author{
Uddin $\mathrm{MB}^{1}$, Ahmed $\mathrm{MU}^{2}$, Haque MA ${ }^{3}$, Hussain $\mathrm{MD}^{4}$, Hossain $\mathrm{SME}^{5}$
}

\begin{abstract}
Introduction: There is a paucity of published data on the type of surgical conditions that affect the UN personnel of different countries setup and the spectrum of surgical operations performed for these patients. Such information are necessary for assessing the impact of surgical conditions, both elective and emergency, on the health of UN peacekeepers from different races and nationalities and for setting priority to improve the surgical care.
\end{abstract}

Objectives: To ascertain highest possible standard of surgical care to be ensured in an international arena for optimal outcome.

Materials and methods: Five years retrospective study was carried out in Bangladesh level II hospital (BANMED), UNMIL located at Suakoko district of Liberia from April 2007 to April 2012 comprising of all major and minor surgical cases with different types of dressings done.

Results: A total 83 major, 567 minor and 3924 dressings were done. The majority of operations were emergency cases of which $73.49 \%$ were of major and $78.30 \%$ were minor surgery. While $26.50 \%$ of major and $21.69 \%$ of minor surgery were elective cases. All were male patients in cases of major operations and $93.29 \%$ for minor cases as most of the peacekeepers were male personnel. The most frequent cases were acute appendicitis, inguinal hernia and polytrauma cases.
Highest number of patients was $28(33.73 \%)$ from 26-30 years age group. There were 3 minor postoperative complications with nil mortality rates.

\section{Conclusion:}

The surgical unit of a level-II hospital has to work in an adverse situation of a conflict area with various limitations. So it is very important to provide highest possible standard of surgical care to be ensured in terms of staff, equipments, logistic support and with a motivated surgical team in an international arena for optimal outcome.

Key-Words: Bangladesh level II hospital, UNMIL, Emergency Surgery, Elective Surgery.

\section{Introduction}

The history of disease is at least as old as the history of mankind. In ancient Egypt, papyri have been found dealing with medicine, surgery, obstetrics and gynecology. The Edwin Smith papyrus written in about $1600 \mathrm{BC}$ is one of the oldest and is of great interest to surgeons. The practice of surgery had evolved from the ancient primitive ways to recent advanced surgical procedure through all these long-time ${ }^{1}$. Surgery is at the end of the spectrum of the classic curative medical model and as such has not been routinely considered as part of the traditional public health model. However, no matter how successful prevention strategies are surgical condition will always

1. Lt Col Md. Borhan Uddin, MBBS, FCPS, Graded Spl in Surgery, CMH, Chitagong. 2. Brig Gen Mohsen Uddin Ahmed, MBBS, MPH, Dy Comdt \& Dir Trg, AFMC, Dhaka Cantt. 3. Col Mohammad Anwarul Haque, MBBS, FCPS, Cl Spl in Radiology, CMH, Jessore. 4. Lt Col Muhammad Delwar Hussain, MBBS, FCPS, Cl Spl in Anaesthesiology, CMH, Ghatail. 5. Maj SM Eqbal Hossain, MBBS, MCPS, Graded Spl in Surgery, BGB Hospital, Satkania, Chittagong. 
account for a significant portion of a population's disease burden particularly where the incidence of trauma, war injuries and road traffic accidents are common.

United Nations (UN) peace keeping operation is based on the principle that presence of an impartial force on the ground can ease tension between hostile parties and create an environment for political negotiation leading to a peaceful solution of conflicts ${ }^{2}$.

Liberia faced two consecutive civil wars. First one was running from 1989 to 1996 and 2nd one 1999 to 2003 in which about 250,000 people were killed and further displaced a million others into refugee camps in neighboring countries ${ }^{3}$. The UN peace keepers were deployed on 1st October 2003 along with its medical support unit. Bangladesh was the first troop contributing country in this mission and one level-II hospital was established in sector B, Gbarnga, Suakoko district. The mission of level II medical support (brigade or sector level) is to provide second line health care, emergency resuscitation and stabilization, limb and life-saving surgical intervention, basic dental care and casualty evacuation to the next echelon ${ }^{3}$. The requirement of surgical care differs in case of these peace keepers from the civil perspective, because most of them are from fighting forces, physically and mentally fit, come from various races and geographic conditions from different areas of the world. Moreover they are more prone to suffer from injuries in operational/war condition. The burden of diseases worldwide due to surgical conditions alone is estimated to be $11 \%$ with the lead issues being injury, malignancy, congenital anomalies, and so on ${ }^{4}$. Each year, intentional and unintentional injuries account for nearly 1 in 10 deaths worldwide ${ }^{5}$.

Level II medical unit as per UN standard provides health care to peace keeping force upto 1000 in strength with the capacity of treating up to 40 ambulatory patients per day. It can perform limb and lifesaving surgery such as laparotomy, appendicectomy, thoracocentesis, wound exploration and debridement, fracture fixation and amputation. This must have the capacity to perform 3-4 major surgical procedures under general anesthesia per day ${ }^{3}$. Members of military contingent, military observers, UN police, UN international staff members, UN locally recruited staff members, local police and local population report to the hospital for medical aid ${ }^{6}$.

By collecting pertinent data from patient's medical record, substantial insight can be obtained into the types of surgical diseases, the age at which these disease conditions present and their burden of in patient survice. Although these data are obviously referral and access based, they can provide useful information on morbidity in the community ${ }^{7}$.

Little is known about the surgical diseases that affect the multinational forces and locals of the peace keepers in this region of Liberia. We analyzed the pattern of surgical pathologies, operative outcomes and inpatient burden of patients who required surgical intervention in this hospital from April 2007 to April 2012.

\section{Materials and Methods}

This retrospective study has been carried out in Bangladesh level-II hospital UNMIL at Gbarnga, Suakoko district, Liberia of West Africa. Among the surgical cases who underwent operative procedure both as indoor and OPD patient during the period of April 2007 to April 2012. The level II hospital is the second level of medical unit and the first level where surgical expertise and facilities are available. The surgical unit consists of surgical ward, modern operation theatre with recovery and immediate post operative / intensive care room. The key technical staff includes one general surgeon, one orthopaedic surgeon, one anesthesiologist, two OT assistants, two intensive care assistants and 2 other nurses with varsity experiences in surgical care. All patients irrespective of age, sex, religion and nationality operated in this hospital were included is this study. OPD and indoor cases were recorded separately. Local and non entitled patients were operated mainly as OPD cases and a few cases were observed in the ward for certain period. The medical data (patient files and operating room log books) of all surgical patient operated within the period were used to collect relevant data of variables. 


\section{Results}

From April 2007 to April 2012 a total 83 major, 567 minor surgery and 3924 dressings were done at Bangladesh level-II hospital, UNMIL (Table-I).

Table-I: Yearly distribution of total no of operated cases $(n=4574)$

\begin{tabular}{|l|l|l|l|}
\hline \multirow{2}{*}{ Year } & \multicolumn{3}{l}{ No of operated case } \\
\cline { 2 - 4 } & Major & Minor & Dressing \\
\hline $2007-2008$ & 17 & 111 & 620 \\
\hline $2008-2009$ & 12 & 120 & 710 \\
\hline $2009-2010$ & 22 & 113 & 830 \\
\hline $2010-2011$ & 16 & 100 & 706 \\
\hline $2011-2012$ & 16 & 123 & 1058 \\
\hline Total & 83 & 567 & 3924 \\
\hline
\end{tabular}

Of this cohort surgical patients $22(26.5 \%)$ had major surgery at elective basis while $61(73.49 \%)$ were emergency surgical cases (Table-II).

Table-II: Distribution of surgical cases according to type of operation $(n=650)$.

\begin{tabular}{|l|l|l|l|l|}
\hline Type & Major surgery & Percentage & Minor surgery & Percentage \\
\hline Emergency & 61 & 73.49 & 444 & 78.30 \\
\hline Elective & 22 & 26.50 & 123 & 21.69 \\
\hline Total & 83 & 100 & 567 & 100 \\
\hline
\end{tabular}

All the major surgical patients were male by sex because most of the peacekeepers were male. The number of entitled patient in case of major surgery, minor surgery and dressing were $80(96.38 \%)$, $262(53.79 \%)$ and $981(25 \%)$ respectively (Table-III).

Table-III: Distribution of operated cases according to entitlement $(n=3924)$.

\begin{tabular}{|l|l|l|l|l|l|l|l|l|}
\hline \multicolumn{2}{|l|}{ Major surgery } & \multicolumn{3}{l|}{ Minor surgery } & \multicolumn{3}{l|}{ Dressing } \\
\hline Entitled & Nonentitled & Total & Entitled & Nonentitled & Total & Entitled & Nonentitled & Total \\
\hline $\begin{array}{l}80 \\
(96.38 \%)\end{array}$ & 03 & 83 & 262 & 305 & 567 & 981 & 2943 & 3924 \\
\hline
\end{tabular}

In minor surgical cases, $529(93.29 \%)$ were male and $38(6.71 \%)$ were female. The ratio is 13.92:1(Table-IV).

Table-IV: Sex distribution of operated cases $(\mathrm{n}=650)$

\begin{tabular}{|l|l|l|l|l|}
\hline Type & Major surgery & Percentage & Minor surgery & Percentage \\
\hline Male & 83 & 100 & 529 & 93.29 \\
\hline Female & - & 0 & 38 & 6.71 \\
\hline Total & 83 & 100 & 567 & 100 \\
\hline
\end{tabular}

The average patient age was 29.76 years. A total of $2(2.4 \%)$ were from paediatric age group (less than 15 years of age). The highest proportion of patients, $28(33.73 \%)$ were under the category of age 26-30 years (Table-V).

Table-V: Age distribution of operated major cases $(\mathrm{n}=83)$

\begin{tabular}{|l|l|l|}
\cline { 2 - 3 } Age group & No of cases & Percentage \\
\hline $11-15$ & 2 & 2.40 \\
\hline $16-20$ & 1 & 1.20 \\
\hline $21-25$ & 12 & 14.45 \\
\hline $26-30$ & 28 & 33.73 \\
\hline $31-35$ & 18 & 21.68 \\
\hline $36-40$ & 15 & 18.07 \\
\hline $41-45$ & 4 & 4.80 \\
\hline $46-50$ & 3 & 3.60 \\
\hline Total & 83 & 100 \\
\hline
\end{tabular}

The descriptive feature of operated major surgical patients is displayed in (Table-Vl).

Table-VI: Distribution of major surgical operations from April 2007 to April 2012 (n=83)

\begin{tabular}{|l|l|l|l|}
\hline Name of the disease & Name of operation & $\begin{array}{l}\text { No of patients } \\
\text { (n=83) }\end{array}$ & Percentage \\
\hline $\begin{array}{l}\text { 1. Acute appendicitis } \\
\text { 2. Perforation of chronic } \\
\text { duodenalulcer }\end{array}$ & $\begin{array}{l}\text { Appendicectomy } \\
\text { Laparotomy and repair }\end{array}$ & 37 & $44.57 \%$ \\
with peritoneal toileting & & $01.2 \%$ \\
\hline 3. Inguinal hernia & $\begin{array}{l}\text { Herniotomy and } \\
\text { herniorraphy }\end{array}$ & 10 & $12.04 \%$ \\
\hline 4. Fistula in ano & Fistulectomy & 05 & $06.02 \%$ \\
\hline 5. Chronic fissure in ano & Lateral sphincterotomy & 03 & $03.6 \%$ \\
\hline 6. Haemorrhoid & Haemorrhoidectomy & 02 & $02.4 \%$ \\
\hline 7. Bullet injury arm & $\begin{array}{l}\text { Surgical toileting with } \\
\text { repair }\end{array}$ & 01 & $01.2 \%$ \\
\hline 8.Shoulder dislo cation & Closed reduction & 08 & $09.6 \%$ \\
\hline 9. Colles' fracture & Closed reduction & 04 & $04.8 \%$ \\
\hline 10. Fracture shaft of radius & Closed reduction & 02 & $02.4 \%$ \\
\hline $\begin{array}{l}\text { 11. Fracture shaft of } \\
\text { radius and ulna }\end{array}$ & ORIF & 02 & $02.4 \%$ \\
\hline 12. Fracture patella & ORIF & 02 & $02.4 \%$ \\
\hline 13. Fracture Calcaneus & ORIF & 01 & $01.2 \%$ \\
\hline 14. Dislocation of elbow joint & Closed reduction & 01 & $01.2 \%$ \\
\hline 15. Fracture TibiaFibula & ORIF & 01 & $01.2 \%$ \\
\hline 16. Fracture Tibia & ORIF & 01 & $03.6 \%$ \\
\cline { 2 - 3 } & Closed reduction & 02 & \\
\hline
\end{tabular}

The five most frequent cases were Acute appendicitis 37(44.57\%), Inguinal hernia 10(12.04\%), Dislocation of shoulder joint 08(9.6\%), Fistula in ano 05(6.02\%) and Colles' fracture $04(4.8 \%)$. Of the total only $3(3.6 \%)$ had mild postoperative complications-Seroma $2(2.4 \%)$ and wound infection 1(1.2\%). Postoperative deaths were nil (Table-VIl). 
Table-VII: Distribution of intra/postoperative complications of operated cases $(n=83)$

\begin{tabular}{|l|l|l|l|l|}
\hline Name of the operation & $\begin{array}{l}\text { Total } \\
\text { No } \\
(\mathbf{n = 8 3 )}\end{array}$ & Complication & $\begin{array}{l}\text { Type of } \\
\text { complication }\end{array}$ & Percentage \\
\hline 1. Acute appendicitis & 37 & 02 & Seroma & $2.4 \%$ \\
\hline 2. Perforation of chronic duodenal ulcer & 01 & - & - & - \\
\hline 3. Inguinal hernia & 10 & - & - & - \\
\hline 4. Fistula in ano & 05 & - & - & - \\
\hline 5. Chronic fissure in ano & 03 & - & - & - \\
\hline 6. Haemorrhoid & 02 & - & - & - \\
\hline 7. Bullet injury arm & 01 & - & - & - \\
\hline 8. Shoulder dislocation & 08 & - & - & - \\
\hline 9. Colles' fracture & 04 & - & - & - \\
\hline 1. Fracture shaft of radius & 02 & - & - & - \\
\hline 1. Fracture shaft of radius and ulna & 02 & - & - & - \\
\hline 12. Fracture patella & 02 & - & - & - \\
\hline 13. Fracture Calcaneus & 01 & - & - & - \\
\hline 14. Dislocation of elbow joint & 01 & - & - & - \\
\hline 15. Fracture Tibia-Fibula & 01 & 01 & Wound infection & $1.2 \%$ \\
\hline 16. Fracture Tibia & 03 & - & - & - \\
\hline
\end{tabular}

The mean duration of hospital stay has shown that major /poly trauma cases(fracture tibia-fibula and fracture Calcaneus) had the largest hospital stay (16 days) in comparison to general surgical emergency like perforation of chronic duodenal ulcer 12 days and acute appendicitis 09 days (Table-VIIl).

Table-VIII: The mean duration of hospital stay in days with respective surgical diagnosis from 2007 to 2012

\begin{tabular}{|l|l|l|l|}
\hline Name of the disease & $\begin{array}{l}\text { Min hospital } \\
\text { stay in days }\end{array}$ & $\begin{array}{l}\text { Max hospital } \\
\text { stay in days }\end{array}$ & $\begin{array}{l}\text { Mean } \\
\text { duration }\end{array}$ \\
\hline 1. Acute appendicitis & 07 & 11 & 09 \\
\hline 2. Perforation of chronic duodenal ulcer & 12 & & 12 \\
\hline 3. Inguinal hernia & 04 & 08 & 07 \\
\hline 4. Fistula in ano & 03 & 05 & 04 \\
\hline 5. Chronic fissure in ano & 03 & 05 & 04 \\
\hline 6. Haemorrhoid & 03 & 05 & 04 \\
\hline 7. Bullet injury arm & 01 & & 01 \\
\hline 8. Shoulder dislocation & 01 & 03 & 03 \\
\hline 9. Colles' fracture & 02 & 04 & 03 \\
\hline 10. Fracture shaft of radius & 02 & 04 & 03 \\
\hline 11. Fracture shaft of radius and ulna & 10 & 14 & 12 \\
\hline 12. Fracture patella & 10 & 12 & 11 \\
\hline 13. Fracture Calcaneus & 16 & & 16 \\
\hline 14. Dislocation of elbow joint & 02 & & 02 \\
\hline 15. Fracture Tibia-Fibula & 16 & & 16 \\
\hline 16. Fracture Tibia & 12 & 16 & 14 \\
\hline
\end{tabular}

Regarding the minor cases most of the patients were non entitled $(53.79 \%)$ and emergency $(78.30 \%)$ of which most them were traumatic origin. Highest numbers of cases were due to RTA $186(32.80 \%)$. A significant numbers of minor cases were hand and foot infection 68 (11.99\%) due to trauma (Table-1X).
Table-IX: Distribution of patients of minor surgical procedures $(n=567)$

\begin{tabular}{|l|l|l|l|}
\hline Name of the disease & Name of operation & $\begin{array}{l}\text { No. of patients } \\
(\mathbf{n}=567)\end{array}$ & Percentage \\
\hline 1. Injuries due to RTA & $\begin{array}{l}\text { Surgical toileting and } \\
\text { repair }\end{array}$ & 186 & 32.80 \\
\hline 2. Cut injury & Repair & 112 & 19.75 \\
\hline 3. Lipoma & Excision & 30 & 5.29 \\
\hline 4. Sebaceous cyst & Excision & 24 & 4.23 \\
\hline 5. Mole & Excision & 10 & 1.76 \\
\hline 6. Corn & Excision & 15 & 2.64 \\
\hline $\begin{array}{l}\text { 7. Abscess with } \\
\text { cellulite-hand sand foot }\end{array}$ & Incision and drainage & 68 & 11.99 \\
\hline 8. Gluteal abscess & Incision and drainage & 25 & 4.40 \\
\hline 9. Perianal abscess & Incision and drainage & 16 & 2.82 \\
\hline 10. Abscess on other sites & Incision and drainage & 25 & 4.40 \\
\hline 11. Paronychia & Nail avulsion & 15 & 2.64 \\
\hline 12. Foreign body-hand and foot & Removal of foreign body & 14 & 2.46 \\
\hline 13. Tendon injury & Repair & 12 & 2.11 \\
\hline 14. Miscellaneous & & 15 & 2.64 \\
\hline Total & & 567 & 100 \\
\hline
\end{tabular}

Most of the major surgical cases were from Bangladesh (47.98\%) and (32.53\%) were in Pakistan (Table-X).

Table-X: Country wise distribution of operated major surgical cases $(n=83)$

\begin{tabular}{|l|l|l|}
\hline Name of the country & Total no operated cases & Percentage \\
\hline Bangladesh & 39 & 47.98 \\
\hline Pakistan & 27 & 32.53 \\
\hline Liberia & 10 & 12.04 \\
\hline Nigeria & 05 & 6.02 \\
\hline Sreelanka & 01 & 1.20 \\
\hline China & 01 & 1.20 \\
\hline Total & 83 & 100 \\
\hline
\end{tabular}

\section{Discussion}

This study revealed that there was a prevailing wide variety of surgical diseases among the UN peace keepers of different country and local Liberian people. The Bangladesh level-II hospital (BANMED), UNMIL was established at Gbarnga, in Suakoko district of Liberia of West Africa. As other mission areas around the globe under UN mandate it provides medical care to the peace keepers and the local populations to some extent ${ }^{8}$. This hospital renders medical care to about 3000 UN personnel and the local people for humanitarian ground all though the task of level-II medical unit is to provide primary health care to a peace keeping force of up to 1000 in strength $^{4}$. It is a well known fact that health facility data are ice-berg clues for the huge problem in the community.

Many of the surgical pathologies are benign and can be prevented before they cause ill health or their serious consequences can be averted if they are recognized earlier and managed in time. Different type of fractures and trauma cases due to RTA, wound infection and abscesses are the classical example. 
This study also suggest that ailment due to trauma was higher, increasing the length of hospital stay (i.e cost). The possibility of subsequent complications is also high. A significant portion of surgical conditions causing major degree of ill health, disability and mortality is trauma especially following road traffic accident and of course with the largest mean hospital stay. It indicates increased work burden and increased cost incurred. Surgical diseases are still a big burden in the health system and hence, to avoid savagable life loss, disability and improve quality of life, surgical care should be given due priority with regard to awareness creation to public, strengthening overall the surgical care: staffing, equipping and monitoring.

Other prospective studies with both quantitative and qualitative aspects required before giving definitive recommendation on the quality of surgical care the hospital is offering.

Sexually transmitted diseases (STD) and AIDS are occupational diseases affecting the military, including UN peace keeping troops and observers. A prevalence rate of as high as $10-30 \%$ has been found among military personnel ${ }^{4}$. The rate is estimated to be much higher than the respective general population during deployment is a conflict area. Peace keeping soldiers have a higher probability of being infected with HIV then of being killed in military action?. So all the medical personnel should be aware and to adopt universal precautions in handling patients, particularly during resuscitation and intravenous procedures. Medical wastes and consumables should be ensured of proper disposal and decontamination.

\section{Conclusion}

The surgical unit of a level-II hospital has to work in an adverse situation of a conflict area with various limitations of working environment and with a multinational community having different languages, culture, religion, and socio economic background. So it is very important to provide highest possible standard of surgical care. As such an improved institutional surgical care to be ensured in terms of staff, equipments, logistic support and with a motivated surgical team in an international arena for optimal outcome.

\section{References}

1. MAR Al-Fallousi, Postgraduate Surgery: The candidate's guide 2nd ed. Oxford: Butterworth-Heinemann; 1998. p. 616-7.

2. Handbook of United Nations Multi dimensional Peacekeeping Operations.Medical Support Manual for United Nations Peackeeping Operations. 2nd ed, NewYork: United Nations; 1999: 13-9

3. en.wikipedia.org/wiki/first-liberian_civil_war.

4. Structure of Medical Support in Peacekeeping Operations. Medical Support Manual for United Nations Peacekeeping Operatins. 2nd ed, New York: United Nations; 1999: 13-9

5.Wright IG, Waker IA, Yacoub MH. Specialist Surgery in the developing world: Luxury or necessity: Anaesthesia 2007 October; 62 (Supp 1): 84-9

6. Health Care policies and Procedures. Medical Support Manual for United Nations Peacekeeping Opertions. 2nd ed. NewYork: United Nations; 1999: 43-56

7. Debas HT, Gosselin R, Mc Cord C, Thind A. Surgery. In: Jamison DT, Breman JC, Measham AR, Alleyne G, Claeson M, Evans DB, Jha P, Mills A, Musgrove P, editors. Disease Control Priorities in Developing Countries. 2nd ed. Washington DC: World Bank;2006.p.1245-59.

8. Mission's hospital gives top medical care. Available at_www. relief web.int/rw/RWB,NSF/db 900SID/RMOI-6 FT52E

9. Protect yourself, and those you care about, against HIV/ AIDS. 1st ed. NewYork: United Nations; 1998: 3-7 